University of Nebraska - Lincoln

DigitalCommons@University of Nebraska - Lincoln

Faculty Publications: Department of Entomology

2020

\title{
First Description of the Female of the Rare Megasoma lecontei Hardy (Coleoptera: Scarabaeidae: Dynastinae: Dynastini)
}

\author{
Brett Ratcliffe \\ University of Nebraska - Lincoln, bratcliffe1@unl.edu \\ Guillermo Nogueira \\ Universidad Autónoma de Guadalajara, gnogalg57@yahoo.com.mx \\ Rich Cunningham \\ Chino, CA, Scarab349@aol.com
}

Follow this and additional works at: https://digitalcommons.unl.edu/entomologyfacpub

Part of the Entomology Commons

Ratcliffe, Brett; Nogueira, Guillermo; and Cunningham, Rich, "First Description of the Female of the Rare Megasoma lecontei Hardy (Coleoptera: Scarabaeidae: Dynastinae: Dynastini)" (2020). Faculty Publications: Department of Entomology. 856.

https://digitalcommons.unl.edu/entomologyfacpub/856

This Article is brought to you for free and open access by the Entomology, Department of at DigitalCommons@University of Nebraska - Lincoln. It has been accepted for inclusion in Faculty Publications: Department of Entomology by an authorized administrator of DigitalCommons@University of Nebraska - Lincoln. 


\title{
First Description of the Female of the Rare Megasoma lecontei Hardy (Coleoptera: Scarabaeidae: Dynastinae: Dynastini)
}

\author{
Brett C. Ratcliffe \\ Systematics Research Collections, University of Nebraska State Museum \\ W-436 Nebraska Hall, University of Nebraska \\ Lincoln, NE 68588-0514, USA \\ bratcliffe1@unl.edu \\ Guillermo Nogueira \\ Facultad de Ciencia y Tecnología, Universidad Autónoma de Guadalajara \\ Apdo. Postal 1-440, Guadalajara, Jalisco 45129 MEXICO \\ gnogalg57@yahoo.com.mx \\ AND \\ Rich Cunningham \\ 889 Walnut Avenue \\ Chino, CA 91710, USA \\ Scarab349@aol.com
}

\begin{abstract}
Megasoma lecontei Hardy is the most rarely collected of all species of Megasoma Kirby, and the female remained undescribed. A description and illustrations of the female of $M$. lecontei are provided for the first time based on several specimens from near Cabo San Lucas, Baja California Sur, Mexico. A revised key to the Megasoma species occurring in Baja California Sur, Mexico is presented.
\end{abstract}

Key Words: elephant beetle, morphology, Neotropics, identification key

DOI.org/10.1649/0010-065X-74.1.119

\section{INTRODUCTION}

The genus Megasoma Kirby consists of 16-21 species (depending on the authority) and a number of subspecies. Species in the genus are found from the southwestern USA to northern Argentina. Adults of Megasoma species are collectively known as elephant beetles because of their moderate to large size and long cephalic horn in the male. Adults are characterized by a broadly truncate to emarginate clypeal apex with acute or toothed anterior angles in the male, mandibles with two or three acute teeth, short prosternal process, and tridentate protibia. Males all have a variably developed, bifurcate head horn, and the pronotum is either armed or not.

Hardy (1972) reviewed the North and Central American species of Megasoma. Endrödi (1977, 1985) provided a synopsis of all the species then known. Pictorial treatments of all species of Megasoma were provided by Lachaume (1985), Nagai (2003), Hwang (2011), and Kobayashi (2019).

Megasoma lecontei Hardy is the most rarely collected of all the species and has been found only near
Cabo San Lucas in Baja California Sur, Mexico. As of 2013, less than two dozen males (Figs. 1-2) were known (Ratcliffe et al. 2013). The females (Figs. 3-4) are even more rare, with just a handful of specimens residing in the personal collections of Guillermo Nogueira (Mexico), the late Miguel Morón (Mexico), Rich Cunningham (USA), and Leonelli Milani (Italy). Nogueira and Morón had been planning to describe the female until the untimely passing of Miguel in 2017.

The complete description of the male is found in Ratcliffe et al. (2013), and the female is described here for the first time.

\section{Material and Methods}

The description of the female is based on six specimens collected by Guillermo Nogueira near Cabo San Lucas in the Sierra La Laguna (710-980 m elevation), Baja California Sur, Mexico, in September 2010 and 2011.

Plant names used in the habitat characterization are from Martínez (1979), Rebman and Roberts (2012), Rebman et al. (2016), and Tropicos.org (www.tropicos.org). 

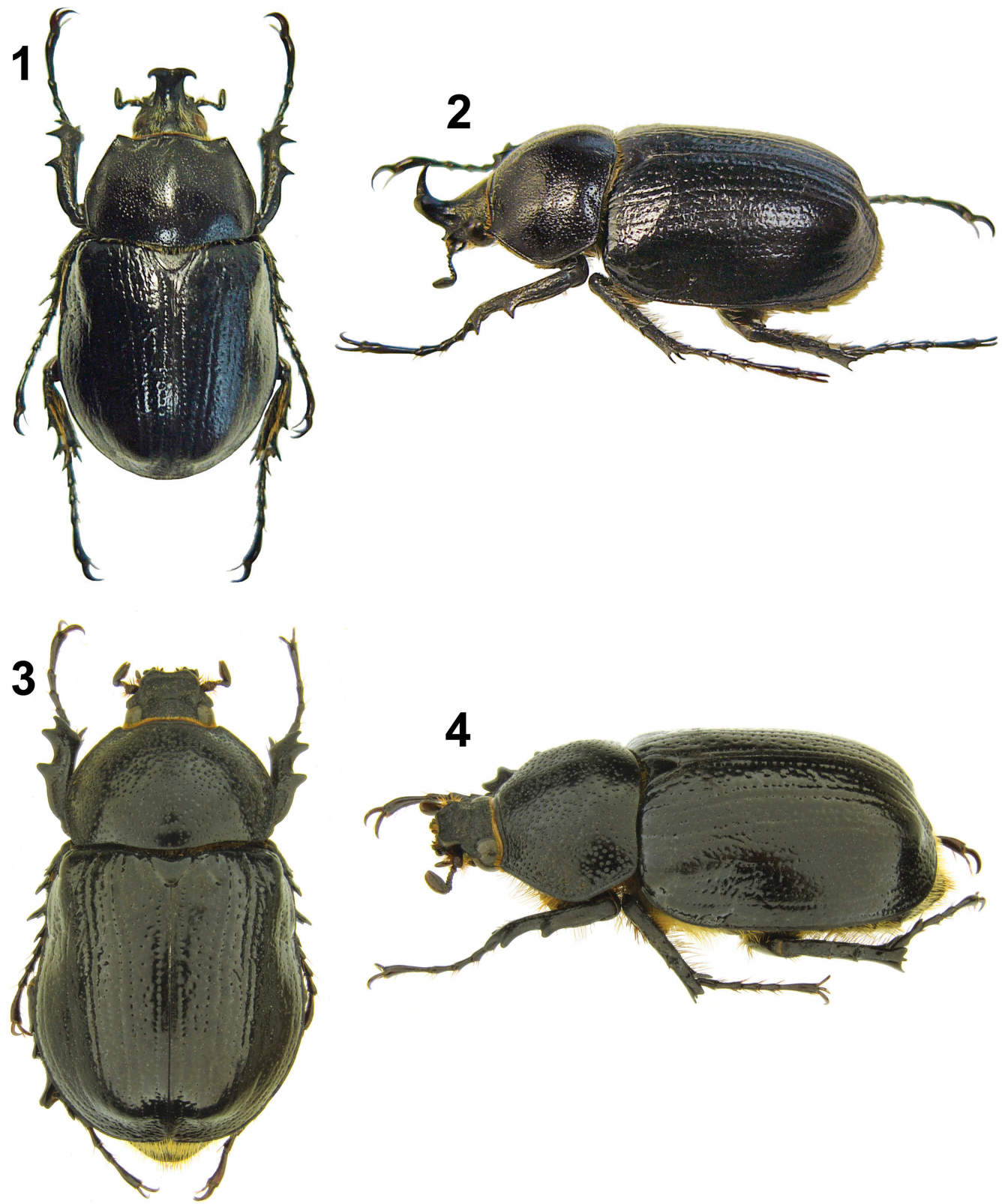

Figs. 1-4. Megasoma lecontei. 1-2) Male, dorsal and lateral views, respectively; 3-4) Female, dorsal and lateral views, respectively.

\section{Megasoma lecontei Hardy, 1972}

(Figs. 1-16)

Female Description. $n=5$. Length from clypeal apex to elytral apex $24.7-34.1 \mathrm{~mm}$; width across humeri 14.5-20.0 mm. Color black. Head: Frons coarsely rugose. Clypeus rugose and with a transverse, binodose tubercle on base; apex broadly rounded either side of emargination (Figs. 3-5). Interocular width equals 3.3 transverse eye diameters. Antenna with 10 segments, club subequal in length to antennomeres 2-7. Pronotum: Surface glabrous with large, dense punctures, minutely aciculate between punctures; punctures becoming denser on sides and in anterior 

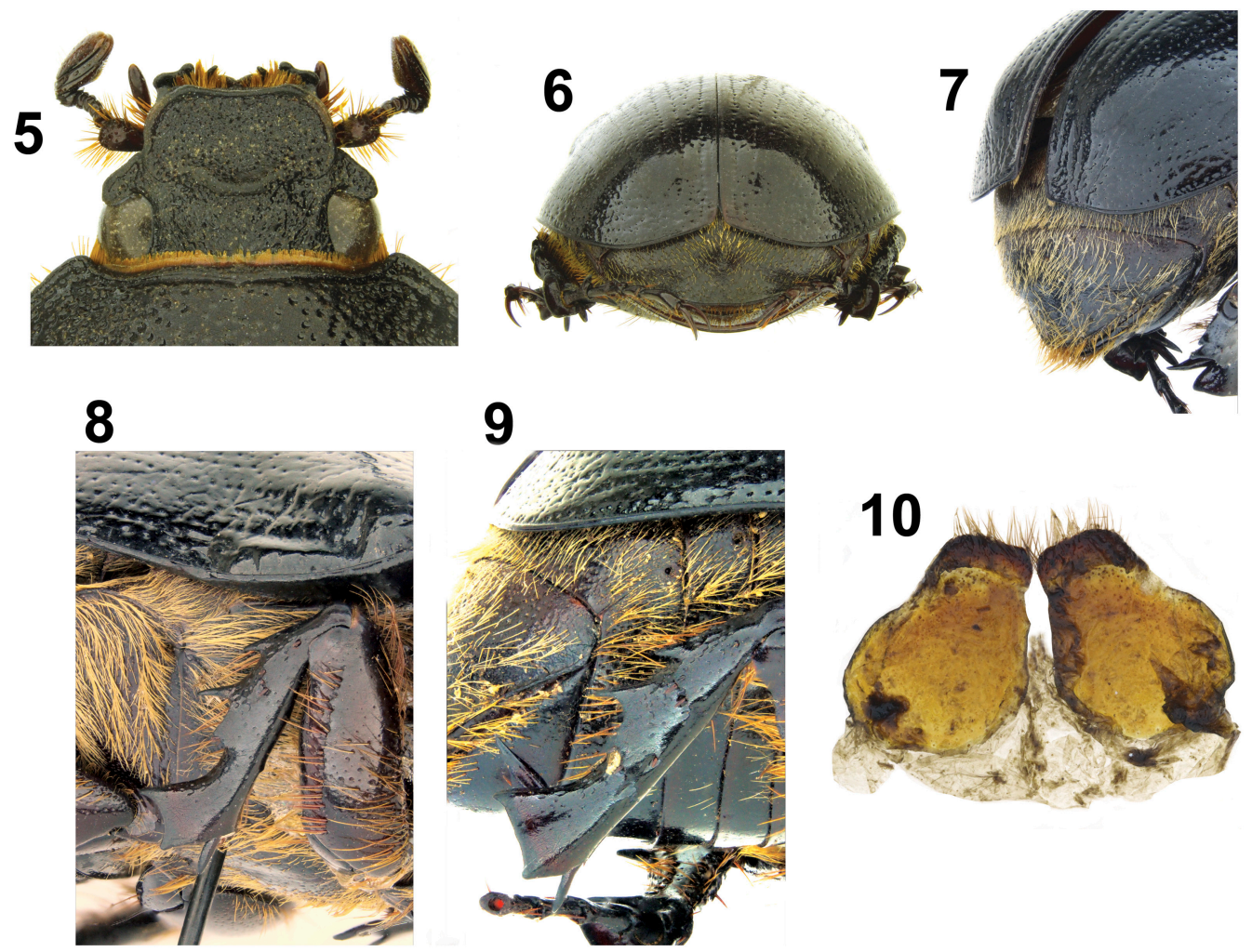

Figs. 5-10. Megasoma lecontei, female. 5) Head showing detail of clypeal apex and transverse tubercle; 6-7) Pygidium, caudal and lateral views, respectively; 8-9) Meso- and metatibiae, respectively, lateral views; 10) Genital plates, ventral view.

angles. Base lacking marginal bead. Elytra: Surface shiny, glabrous, with poorly defined punctate striae; punctures of striae and intervals large, umbilicate. Punctures in striae separated by about 1 puncture diameter, punctures of intervals separated by about 1-3 puncture diameters. Sutural stria not an impressed line, instead a row of punctures. Pygidium: Surface on basal half with moderately large, dense punctures; apical half roughened or weakly rugose, all punctures setigerous; setae long, dense, light yellowish brown (Figs. 6-7). Surface weakly convex in lateral view. Legs: Protibia tridentate, basal tooth strongly removed from other teeth (Fig. 3). Meso- and metatibiae on basal fourth and on middle each with 2 large spines and 1 subacute angle (Figs. 8-9). Apex of metatibia obliquely truncate and with large, triangular angle at middle. Apex of $1^{\text {st }}$ metatarsomere elongated into short, stout spine. Venter: Prosternal process short, triangular, laminate. Genital plates: Pear-shaped, apex with long setae (Fig. 10).

Diagnosis. Both sexes of $M$. lecontei are glabrous on the pronotum and elytra, whereas the other two species from Baja California Sur are setose.
Geographic Distribution. Near Cabo San Lucas in the Sierra La Laguna, Baja California Sur, Mexico (Fig. 13).

Temporal Distribution. May (1), August (7), September (9), October (1).

Natural History. Specimens (Figs. 11-12) were collected in an area of arid tropical forest and oakpiñon woodland (Quercus idonea Goldman/ Quercus brandegeei Goldman (Fagaceae) and Pinus cembrodes Zuccarini (Pinaceae)) where the principal vegetation consists of madroño (Arbutus peninsularis Rose \& Goldman, Ericaceae), palo verde (Parkinsonia peninsulare Rose, Fabaceae), palo amarillo (Esenbeckia flava Brandegee, Rutaceae), palo blanco (Lysiloma candidum Brandegee, Fabaceae), palo de arco (Tecoma stans (Linnaeus), Bignoniaceae), palo brea (Parkinsonia praecox (Ruiz \& Pavón), Fabaceae), palo zorrillo (Cassia occidentalis (Linnaeus), Fabaceae), palmita (Nolina matapensis Wiggins, Asparagaceae), palma talco (Erythea brandegeei Purpus, Arecaceae), mauto (Lysiloma divaricatum (Jacquin), Fabaceae), cardón-barbón (Pachycereus pecten-aboriginum Britton \& Rose, Burseraceae), ciruelo (Cyrtocarpa 

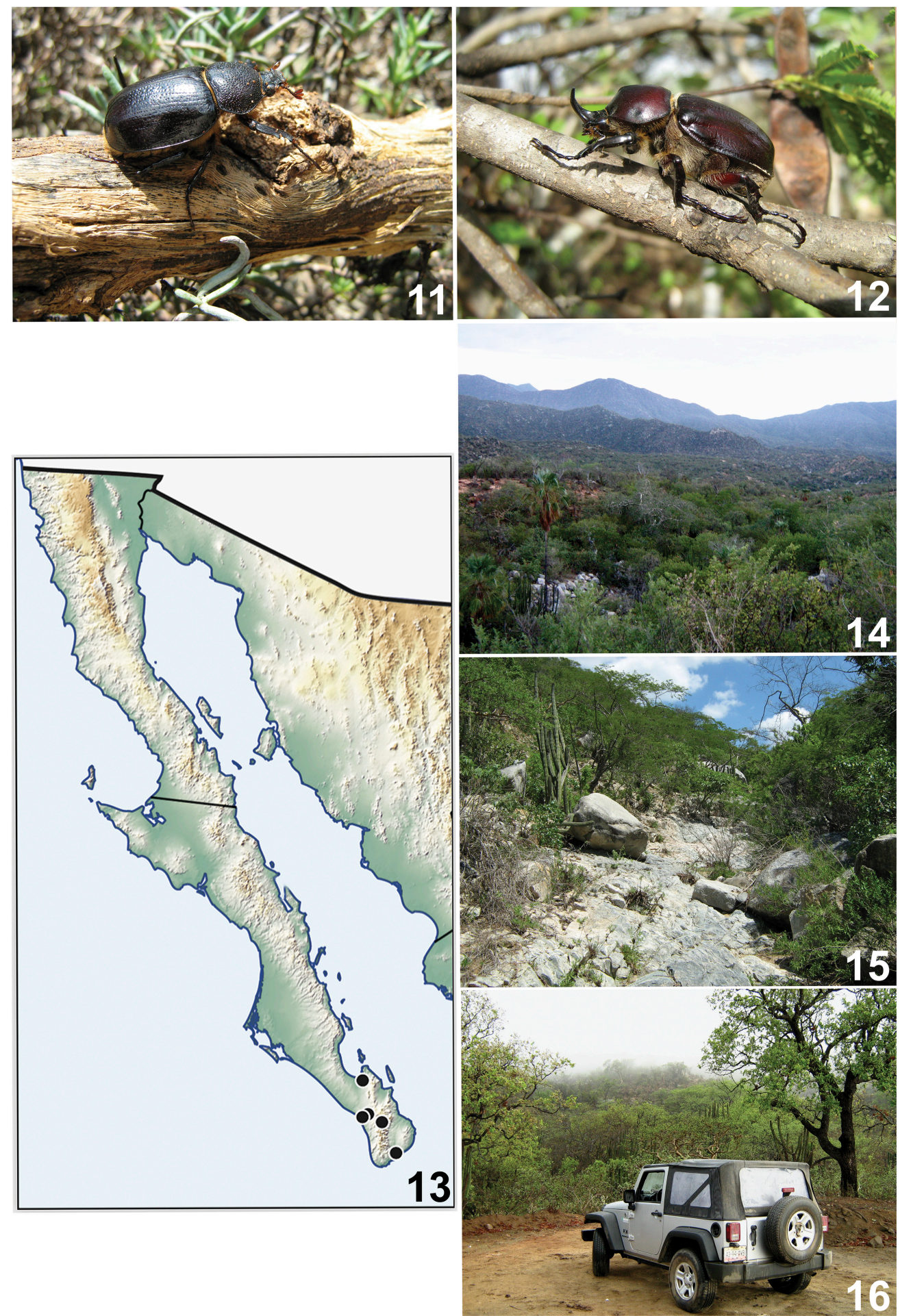

Figs. 11-16. Megasoma lecontei. 11-12) Live female and male, respectively; 13) Distribution; 14-16) Habitat near Cabo San Lucas in the Sierra La Laguna, Baja California Sur, Mexico. Photographs by G. Nogueira. 
edulis (Brandegee), Anacardiaceae), bledo (Celosia floribunda A. Gray, Amaranthaceae), huinol (Acacia cymbispina Sprague \& Riley, Fabaceae), jacolosuchil (Plumeria acutifolia Poiret, Apocynaceae), torote (Pachycormus discolor (Bentham), Anacardiaceae), yucca (Yucca valida Brandegee, Agavaceae), and mesquite (Acacia greggii A. Gray) (Figs. 14-16).

\section{Key to the Species of Adult Megasoma from Baja California Sur, Mexico}

1. Pronotum and elytra glabrous (Figs. 1-4) ... M. lecontei Hardy

1'. Male elytra and pronotum with recumbent, pale setae. Female elytra with recumbent setae on posterior half or just near apices and often on lateral pronotal margins

2. Male pronotum with anterior angles angulate (normal). Female frons with simply rounded or conical tubercle .... M. cedrosum Hardy

$2^{\prime}$. Male pronotum with anterior angles produced into short, acute horns projecting obliquely. Female frons with transversely binodose tubercle

M. thersites LeConte

\section{ACKNOWLedgments}

We gratefully acknowledge Leonello Milani (Milan, Italy) for providing additional morphological information for the female specimen in his collection. We thank Biol. Oscar Cibrián Ornelas (Universidad Autónoma de Guadalajara, Mexico) for specimen preparation and assistance in the field.

\section{References Cited}

Endrödi, S. 1977. Monographie der Dynastinae (Coleoptera) 6. Tribus Dynastini. II. Acta Zoologica Academiae Scientiarum Hungaricae 23: 37-86.
Endrödi, S. 1985. The Dynastinae of the World. Dr. W. Junk Publisher, Dordrecht, The Netherlands, $800 \mathrm{pp}$.

Hardy, A. R. 1972. A brief revision of the North and Central American species of Megasoma (Coleoptera: Scarabaeidae). The Canadian Entomologist 104: 765-777.

Hwang, S.-M.-R. 2011. The Dynastini of the World (Coleoptera: Scarabaeidae: Dynastinae). Nature and Ecology (Academic Series, Volume 4), Seoul, South Korea, 368 pp.

Kobayashi, K. 2019. A synopsis of the genus Megasoma (Coleoptera: Dynastinae) in Central and South America. Be-Kuwa 70: 8-47.

Lachaume, G. 1985. Dynastini 1: Dynastes - Megasoma - Golofa. Les Coléoptères du Monde 5. Sciences Nat, Venette, France, 85 pp.

Martínez, M. 1979. Catálogo de Nombres Vulgares y Científicos de Plantas Mexicanas. Fondo de Cultura Economica, Ciudad de México, Mexico, $1247 \mathrm{pp}$.

Nagai, S. 2003. Be-Kuwa special present Megasoma (in Japanese). Be-Kuwa No. 9: 4-23, 26-30, 33-43.

Ratcliffe, B. C., R. D. Cave, and E. Cano. 2013. The dynastine scarab beetles of Mexico, Guatemala, and Belize (Coleoptera: Scarabaeidae). Bulletin of the University of Nebraska State Museum 27: 1-666.

Rebman, J. P., J. Gibson, and K. Rich. 2016. Annotated checklist of the vascular plants of Baja California, Mexico. Proceedings of the San Diego Society of Natural History 45: $1-352$.

Rebman, J., and R. C. Roberts. 2012. Baja California Plant Field Guide. Sunbelt Publications, El Cajon, CA, $\mathrm{xx}+451 \mathrm{pp}$.

(Received 2 August 2019; accepted 22 December 2019. Publication date 25 March 2020.) 